\title{
Perceptions About Ethical Behavior Among Undergraduate Students Attending Religiously-Affiliated Institutions
}

Amy Vandenberg, St. Norbert College, USA

Jason J. Haen, St. Norbert College, USA

Kathleen K. Molnar, St. Norbert College, USA

Thomas W. De Berry, Freed-Hardeman University, USA

Joe W. Cotter, Freed-Hardeman University, USA

\begin{abstract}
By controlling for size and existence of a religious affiliation and gender, this study adds to the literature regarding opinions of undergraduate business students about the ethical nature of both academic and business related actions. Analysis of student survey data from two institutions similar in these characteristics continues in this longitudinal study. After the data were separated by gender, ethical perceptions of male students significantly differed for businessrelated dishonest acts for those male students who had taken two or more courses in religion, but church service attendance did not seem to have any effect. This may suggest that taking more courses (or having more dialogs) in which moral issues beyond academics are discussed may affect male student perceptions of ethical issues outside the institution.
\end{abstract}

Keywords: Cheating (Education); Student Attitudes; Business Ethics; Religious Affiliation; Institution

\section{INTRODUCTION}

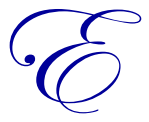

vidence suggests that business students have differing opinions of actions that are ethical and those that are not, and that these views may be related to the types of institutions the students attend (Comegys, 2010; Davis, 1993; Molnar, Kletke \& Jenkel, 2009). Results of previous research have been inconsistent regarding the relationship between business students' perceptions about ethical behavior and the characteristics of the institutions attended (Lawson, 2004; Smyth \& Davis, 2004). Other studies (Cole \& Smith, 1995; Knotts, Lopez \& Mesak, 2000; Ruegger \& King, 1992) found that gender has a significant impact on the ethical judgments of students when asked about business situations. Females were found to be more ethical. Previous studies by this research team (Cotter, De Berry, Haen, Molnar \& Vandenberg, 2016, 2017) explored this relationship by controlling for the existence of a religious affiliation of the institutions, institution size, and respondents' gender. Institution 1 is a small, private, Catholic, liberal arts college in the Midwest, and Institution 2 is a small, private, Christian university in the Southeast United States. Both institutions have enrollments of approximately 2,000 students.

The current study continues this previous research by considering the effect of attendance of church services (defined in this paper as "religiosity"), and also the number of courses in religion taken by student respondents. In the following sections, previous research regarding student ethical perceptions is presented, followed by a discussion of the research methods, results, and implications of the current study.

\section{LITERATURE REVIEW AND HYPOTHESIS DEVELOPMENT}

This study expands the previous research by this team by also controlling for a component of religiosity (church service attendance) and the number of courses in religion completed. This study follows the approach of previous studies by considering whether students attending similar type and size institutions exhibit comparable ethical perceptions. The influence of the type and size of institution attended on the ethical perceptions of students has been widely studied, with inconsistent results reported. Molnar, et al. (2009) found students at a small, private, religiously- 
affiliated institution consider cheating less acceptable than do students at public universities, regardless of size. Davis (1993) found that students at small, private, liberal arts colleges cheat less than students at large universities, whether they are public or private schools. Comegys (2010) found evidence that students attending religiously-affiliated schools have more ethical attitudes towards business than do those students attending non-religiously-affiliated schools; sizes of the six schools included in the study were not disclosed.

Smyth, Davis and Kroncke (2009) found the perceptions of students attending a public college were more unethical, but only for the worst types of behavior. The three schools included in the study all had enrollments of less than 3,500. Brown and Choong (2005) found no relationship between the type of school attended and either the participation in academically dishonest acts or the ethical perceptions of those acts. The public university in the study was reported as medium-sized, while the religiously-affiliated school was reported as small.

The 2016 study (Cotter et al., 2016) conducted by this research team found no overall difference between the two institutions in the ethical perceptions of the students. However, in the 2017 study (Cotter et al., 2017), a significant overall difference $(\mathrm{p}=.003)$ was found. The students at Instiution 1 were found to be more ethical.

The varying results from these studies call into question whether the strongest relationship between students' ethical perceptions is to the type of institution attended, the size of institution attended, both, or neither. Instead, perhaps the most robust relationships of students' ethical perceptions are specific to other institutional or student characteristics.

The previous studies conducted by this research team also took into consideration the type of dishonest acts, academic or business. This variable was taken into consideration again in this study. Most previous research has found that students view both academic and business dishonest acts similarly. For example, Smyth and Davis (2004) and Lawson (2004) found that most students had similar ethical views regarding academic and business situations. Similarly, Nonis and Swift (2001) and Sims (1993) found students who cheated in school tended to cheat more in the workplace. However, these previous studies included only one institution or did not control for the type and size of institution attended.

To address the possibility of the impact on results of survey instruments containing both academic and business activities, the survey instrument for this research grouped questions into academic and business categories. Thus, the following null hypotheses were tested:

H1a: The acceptability of academic dishonest acts will not be significantly different between students attending religiously-affiliated schools of similar size.

H1b: The acceptability of business dishonest acts will not be significantly different between students attending religiously-affiliated schools of similar size.

The 2016 study (Cotter et al., 2016) conducted by this research team found a significant difference for business-related questions but not for academic-related questions. Institution 2 students were found to be more ethical for businessrelated questions. It was anticipated that significant differences would once again only be detected for business questions so further analysis focused only on these types of questions.

Similar to the 2017 study (Cotter et al., 2017), this research analyzed the effect of gender differences towards the acceptability of dishonest acts on the results. Numerous studies report that females cheat less often than males (Atmeh \& Al-Khadash, 2008; Guo, 2011; McCabe \& Trevino, 1997; Niiya, Ballantyne, North \& Crocker, 2008; Rakovski \& Levy, 2007; Yang \& Huang, 2013) and Kuntz and Butler (2014) found females deem cheating and plagiarism behaviors less acceptable than do their male counterparts. Other studies (Albaum \& Peterson, 2006; Cole \& Smith, 1995; Knotts et al., 2000; Ruegger \& King, 1992) found that gender has a significant impact on the ethical judgments of students when asked about business situations. Females were found to be more ethical. Further, Simon, Carr, McCullough, Morgan and Oleson (2004) found females were more likely to report a case of academic dishonesty. 
These previous studies suggest that a gender bias may be present, so the data were further separated by gender. Therefore, the following null hypotheses were proposed:

H2a: The acceptability of business dishonest acts will not be significantly different between male students attending religiously affiliated schools of similar size.

H2b: The acceptability of business dishonest acts will not be significantly different between female students attending religiously affiliated schools of similar size.

In the 2017 study (Cotter et al. 2017), males at Institution 2 were again found to be more ethical for business-related questions. No difference was found between the responses of females at the two institutions. It was anticipated that significant differences would once again only be detected for males so additional analysis focused on male responses to business-related questions. To further this area of research, the differences between the males at the institutions in regards to church service attendance and number of courses in religion taken and their possible effect on ethical perceptions were studied. It was found that the males at Institution 2 significantly $(p=0.000)$ attend church services more often and also significantly $(\mathrm{p}=0.000)$ complete more courses in religion.

The concept of religiosity and its effect on ethical perceptions and behavior has been widely studied. Religiosity, as defined by Bloodgood, Turnley and Mudrack (2008, p. 559) is "understanding, committing to, and following a set of religious doctrines or principles." This study is interested in one component of religiosity, namely church service attendance.

Burks and Sellani (2008) found that higher religious commitment did not result in a person being more ethical. Similarly, Baumsteiger, Chenneville and McGuire (2013) concluded that religiosity does not determine a person's ethical positions. Additionally, Wilhelm (2004) found that religious participation did not have a significant effect on moral reasoning, and Willson (2016) reported that religious service attendance did not significantly affect the willingness of students to report receiving too high of a grade on an assignment. These results were supported by Kurpis, Beqiri and Helgeson (2008) who found that church attendance did not significantly affect ethical behavioral intentions.

However, Albaum and Peterson (2006) found participants who reported being very religious were significantly more ethically inclined for business situations. Bloodgood, et al. (2008) and Burton, Talpade and Haynes (2011) found that students who attended religious services more frequently were less likely to cheat. Also, Conroy and Emerson (2004) found that frequent church attendance significantly reduced the acceptability of a number of unethical business practices.

In order to study whether church service attendance is related to the ethical perceptions of male students, the following null hypothesis was tested:

H3: The acceptability of business dishonest acts for male students who more regularly attend church services will not be significantly different from that of male students who attend church services on a less regular basis.

The completion of courses in religion and their effect on ethical perceptions and behaviors also has been widely studied, with inconsistent results. Bath, et al. (2014) found that the completion of required courses in religion did not significantly affect the tendency to cheat, and Conroy and Emerson (2004) found that taking a course in religion did not significantly affect the ethical attitudes of students towards business situations. However, Comegys (2010) concluded that completion of religious studies may affect students' attitudes towards business ethics, but the affect was found to be more pronounced for non-business majors. Burks and Sellani (2008) found that completion of a course in religion resulted in higher moral development, no matter the type of institution.

To study any possible affect that the completion of courses in religion may have on the ethical perceptions of male college students, the following hypothesis was proposed:

H4: The acceptability of business dishonest acts for male students who have completed more courses in religion will not be significantly different from that of male students who have completed fewer such courses. 


\section{RESEARCH METHOD}

The methodology and survey questionnaires were based on previous research studies (Molnar, Kletke, \& Chongwatpol, 2008) for the academic dishonest acts, and added questions from research by (Smyth \& Davis, 2004; Lawson, 2004) for the business dishonest acts. Additional questions regarding frequency of church service attendance and number of courses in religion taken were added to the survey. Following similar procedures to those from 2008, students were asked to complete a paper-based questionnaire asking their perceptions of dishonest acts. Questionnaires were used since the intention to engage in a behavior is a good predictor of behavior (Beck \& Ajzen, 1991). Asking respondents to report perceptions of cheating, rather than how often they engage in cheating, is less threatening and likely to yield more honest responses (Kisamore, Stone \& Jawahar, 2007).

In fall 2016 and spring 2017, surveys were again administered to undergraduate students at Institutions 1 and 2 . The majority of respondents were traditional students who had mainly business-related majors. Survey questions regarding dishonest acts were coded on an interval assumed Likert-scale of 1 to 5, with 1 representing "strongly disagree" with the acceptance of the dishonest act, and 5 indicating "strongly agree" with the acceptance of the dishonest act, as perceived by the subject. Therefore, the lower the overall score, the less likely the student felt it was acceptable to commit the dishonest act. The survey asked how the students felt about academic dishonest acts (such as cheating on assignments or exams) and business dishonest acts (such as dishonest acts in a business environment). Using SPSS, researchers performed independent sample t-test analyses using the dependent variables of user responses to all questions relevant to this research and by categories of academic dishonesty questions and business dishonesty questions. The mean value of the student responses for each category was used. The larger the mean value of the response, the more strongly the student agreed that it is acceptable to commit that type of dishonesty.

\section{RESULTS}

A total of 276 usable questionnaires were collected; 159 were from Institution 1 (the Midwestern Catholic college), and 117 were from Institution 2 (the Southeastern Christian university). The majority of respondents (over 82\%) were businessrelated majors. Approximately $60 \%$ of the respondents were male, and $40 \%$ were female. Sixty-eight percent were underclassmen (freshman and sophomores), and 32\% were upperclassmen (juniors and seniors). Over 78\% of respondents indicated they had a GPA of 3.0 or higher.

The researchers performed a principal factor analysis on the Likert questionnaire using the eleven questions relevant to this study. Two primary factor groups remain (after a varimax rotation), which are labeled academic and business dishonest acts, respectively. The two-factor solution was obtained using eigenvalue greater than one criterion and factor loadings $>0.5$, as suggested by Hair, Anderson, Tatham and Black (1995). Academic dishonest acts had eight questions with factor loadings ranging from .565 to .870 , and business dishonest act questions had three questions with factor loadings ranging from .569 to .805 . This is consistent with other research using this questionnaire.

Table 1 shows the results by institution and by factor (academic versus business categories). The t-tests results by the two factor groups isolated (academic dishonest acts and business dishonest acts) show a significant difference existing between the two institutions for the business dishonest acts factor only. Since there is no significant difference with the academic dishonest acts factor between the institutions, hypothesis H1a should not be rejected. However, these results indicate rejection of hypothesis $\mathrm{H} 1 \mathrm{~b}$ since Institution 1's mean was significantly higher than that of Institution 2 for the business-related questions. This indicates that students from Institution 2 responded more ethically to these types of questions.

Table 1. T-tests by institution

\begin{tabular}{|c|c|c|c|c|c|c|}
\hline Category & College & $\mathbf{N}$ & Mean & Std. Deviation & $\mathbf{t}$ & p-value \\
\hline \multirow{2}{*}{ Academic-Related Only } & 1 & 159 & 12.67 & 4.149 & \multirow{2}{*}{-1.195} & \multirow{2}{*}{0.233} \\
\hline & 2 & 117 & 13.29 & 4.466 & & \\
\hline \multirow{2}{*}{ Business-Related Only } & 1 & 159 & 4.82 & 1.449 & \multirow{2}{*}{2.713} & \multirow{2}{*}{$0.007^{*}$} \\
\hline & 2 & 117 & 4.34 & 1.427 & & \\
\hline
\end{tabular}

*Significant at $\mathrm{p}<.05$ 
To control for gender, this study then split the data into male and female subsets. Table 2 shows the results by institution, by gender, for business-related questions only. The t-tests results show a significant difference existing between the two institutions for the business dishonest acts factor for males only. Therefore, the results indicate rejection of hypothesis $\mathrm{H} 2 \mathrm{a}$, but not $\mathrm{H} 2 \mathrm{~b}$. Institution 1's mean was higher for the business-related questionssuggesting male students of the Institution 2 responded more ethically to the business-related questions than male students from Institution 1 did, whereas responses of female students were not significantly different.

Table 2. T-tests by institution by gender

\begin{tabular}{|c|c|c|c|c|c|c|}
\hline Category & College & $\mathbf{N}$ & Mean & Std. Deviation & $\mathbf{t}$ & p-value \\
\hline \multirow{2}{*}{ Business-Related Only-Males } & 1 & 92 & 4.99 & 1.544 & \multirow{2}{*}{2.534} & \multirow{2}{*}{$0.012^{*}$} \\
\hline & 2 & 74 & 4.41 & 1.384 & & \\
\hline \multirow{2}{*}{ Business-Related Only-Females } & 1 & 67 & 4.58 & 1.281 & \multirow{2}{*}{1.302} & \multirow{2}{*}{0.213} \\
\hline & 2 & 43 & 4.23 & 1.509 & & \\
\hline
\end{tabular}

*Significant at $\mathrm{p}<.05$

Table 3 shows the results for all male students regardless of institution for business-related questions only by amount of church service attendance. (One survey was discarded due to an invalid response for church service attendance). The research team divided church service attendance into two categories: those who attended church services once a month or more, and those who attended less than once a month. The t-tests results based on church service attendance, show no significant differences existing between the business-related responses of the male students. This means $\mathrm{H} 3$ should not be rejected.

Table 3. T-tests by male by mean church service attendance

\begin{tabular}{|c|c|c|c|c|c|c|}
\hline Category & Church Service Attendance & $\mathbf{N}$ & Mean & Std. Deviation & $\mathbf{t}$ & p-value \\
\hline \multirow{2}{*}{ Business-Related Only - Males } & Once a month or more & 103 & 4.64 & 1.349 & \multirow{2}{*}{-.887} & \multirow{2}{*}{0.376} \\
\hline & Less than once a month & 62 & 4.85 & 1.726 & & \\
\hline
\end{tabular}

*Significant at $\mathrm{p}<.05$

Table 4 shows the results for all male students regardless of institution for business-related questions only by number of courses in religion taken. (Three surveys were discarded due to an invalid response for number of courses in religion taken). The research team divided the number of courses in religion taken into two categories: two or more courses taken, and fewer than two courses taken $(<2)$. The t-tests results based on the number of courses in religion taken, show a significant difference exists between the business-related responses of the male students. This means $\mathrm{H} 4$ should be rejected.

Table 4. T-tests by male by mean courses in religion

\begin{tabular}{c|c|c|c|c|c|c}
\hline Category & $\begin{array}{c}\text { Courses in } \\
\text { Religion Taken }\end{array}$ & $\mathbf{N}$ & Mean & Std. Deviation & t & p-value \\
\hline \multirow{2}{*}{ Business-Related Only - Males } & $\geq 2$ & 106 & 4.51 & 1.409 & -2.371 & $0.019^{*}$ \\
\hline
\end{tabular}

*Significant at $\mathrm{p}<.05$

\section{DISCUSSION}

As the research team continues the longitudinal study of ethical perceptions of undergraduate students of the two institutions, the results from the two previous studies were compared. Conflicting results were found. Overall, the results completely reversed between the two previous studies. What could be the cause of this inconsistency? Since the study attempts to control for institution (with both institutions being small, private, and religiously-affiliated) and gender (with males having lower ethical responses than females), what are the major differences between the two institutions which may be causing these differences in responses? In this current study, the researchers noticed that the differences in responses were due to the business-related questions. Perhaps the academic-related ethical issues may be viewed essentially the same by the majority of responding students since they may have encountered similar honor code issues and practices. Also, the same type of individual may be drawn to these similar institutions. 
Therefore, this study focused on controlling both for gender and type of ethical question and thus looked at male student responses relative to the business-related ethical questions.

Two major differences between the institutions are the number of courses in religion required and reported attendance at church services. Institution 2's students report more church service attendance, and it requires more courses in religion in its curriculum than in Institution 1. In this study, the researchers found that male students who had taken more than one course in religion had significantly lower (more ethical) mean responses to the questions related to business ethics than did male students who had taken fewer than two courses in religion. In other words, male students who had taken more than one course in religion were less accepting of business dishonest acts than were males who had taken fewer than two courses in religion. However, church service attendance did not seem to have any effect on male student perceptions of business-related dishonest acts. Could the number of courses in religion explain this difference between institutions in business-related ethical questions? That is, does the difference in curriculum between institutions make a difference in the ethical perceptions of male students regarding business ethics? Institution 2 requires more courses in religion than Institution 1. Our previous studies reported that students' perceptions concerning business-related issues were more ethical in Institution 2, especially for male undergraduate students. By controlling for both gender and type of ethical question, this research may provide a better indicator of what may actually be affecting student perceptions.

Many studies' results disagree about the role of religosity in business ethics (Vitell, 2009). The results of this research suggest not that church service attendance has an affect on student perceptions (since church service attendance itself did not seem to make any difference in student perceptions), but that the amount of curricular time spent discussing religious and social issues may affect student perceptions. Most students have more firsthand experience making academic ethical decisions since they make them on an almost daily basis when in school, and these issues are discussed in many first year experience courses and honor code discussions. However, business decisions may be somewhat foreign to students, resulting in less certainty about how they would handle dishonest acts when engaged in business. This research found that more dialogue in the classroom concerning spiritual/moral/ethical issues beyond academic ethical issues may cause students to further evaluate their perceptions concerning business ethical decisions. Furthermore, Molnar, Kletke and Rampal (2008) found that students find it less acceptable to cheat if they have discussed ethical issues in a course and other research suggest that ethics should be integrated throughout the curriculum (Greening, Kay \& Kummerfeld, 2004, Bodkin \& Stevenson, 2007). Regardless of the type of institution, integrating spiritual/moral/ethical issues (beyond just academic ethical issues) throughout the curriculum may help educate undergraduate students so that they will have the ethical skills and the business knowledge that they need to engage in ethical behaviors when they are employed in the real world. As noted by Bratton and Strittmatter (2013, p. 439), “... the most significant influence on ethical decisions in business may be in the environment in which business practitioners are trained."

\section{LIMITATIONS AND FUTURE RESEARCH}

This study examined the idea that students attending small, religiously-affiliated institutions may have similar perceptions about the ethical nature of various activities when controlling for these two primary characteristics of institutions participating in the research. The number of institutions involved, and the overall number of study participants continues to limit this study. In addition, single measures such as church service attendance and/or number of courses in religion taken cannot capture the diverse nature of what is meant by religiosity.

Continuation of this longitudinal research will yield additional data. Additionally, future extensions of this research may include the introduction of other institutions varying in size and religious affiliation. Other characteristics of the participating institutions such as the existence or absence of a formal honor code, level of employment experience, or geographic regional locations may produce fruitful results in the future when studying relationships between students' ethical perceptions and other specific institutional characteristics. Eventually, the larger data set may be used in expanded research studies that compare results to those from larger institutions, and perhaps those without a religious affiliation. 


\section{AUTHOR BIOGRAPHIES}

Amy Vandenberg is an Assistant Professor of Accounting at St. Norbert College. She earned her MS in tax from the University of Milwaukee her BBA in accounting from St. Norbert College and is a Certified Public Accountant. Her career has been in college education and industry accounting. She teaches courses in financial accounting, business consolidations and federal income tax and has presented at numerous national conferences and published in conference proceedings. She has articles in such publications as The Journal of Behavioral Studies and The Research in Higher Education Journal among others.

Jason J. Haen is an Assistant Professor of Accounting at St. Norbert College. He earned his MBA from the University of Wisconsin - Oshkosh in 2007 and his BBA from St. Norbert College in 1996. He has been a Certified Public Accountant since 1999. His career includes time in public accounting, local government, and not-for-profit organizations. He has published in journals such as The Accounting Educators' Journal, Journal of Academic Ethics and the Journal of Catholic Higher Education.

Kathleen K. Molnar is an Associate Professor in the Business Administration department in the Schneider School of Business at St. Norbert College. Dr. Molnar received her Ph.D. in Management Information Systems from Oklahoma State University, MBA from University of Wisconsin - Oshkosh, and BS from Xavier University. Her research interests are in academic/business ethics and collaborative teaching/learning. She has published in Journal of Business Ethics, Journal of Academic Ethics, Journal of Information Technology among many others.

Thomas W. De Berry is a Professor of Accounting and Economics at Freed-Hardeman University. His PhD (Economics) and MS (Accounting) are from Texas Tech University. He has been a Certified Public Accountant since 1980 and a Certified Fraud Examiner since 2007. He has published numerous articles, including in The CPA Journal and the Journal of Forensic Accounting.

Joe W. Cotter is a retired Assistant Professor of Management with Freed-Hardeman University. His MBA is from the University of Phoenix, and his PhD is from Capella University.

\section{REFERENCES}

Albaum, G., \& Peterson, R. A. (2006). Ethical attitudes of future business leaders: Do they vary by gender and religiosity? Business \& Society, 45(3), 300-321.

Atmeh, M. \& Al-Khadash, H. (2008). Factors affecting cheating behavior among accounting students (using the theory of planned behavior). Journal of Accounting, Business \& Management, 15, 109-125.

Bath, M., Hovde, P., George, E., Schulz, K., Larson, E., \& Brunvatne, E. (2014). Academic integrity and community ties at a small, religious-affiliated liberal arts college. International Journal for Educational Integrity, 10(2), 31-43.

Baumsteiger, R., Chenneville, T., \& McGuire, J. F. (2013). The roles of religiosity and spirituality in moral reasoning. Ethics \& Behavior, 23(4), 266-277.

Beck, L. \& I. Ajzen. (1991). Predicting dishonest actions using the theory of planned behavior. Journal of Research in Personality, 25, 285-301.

Bloodgood, J. M., Turnley, W. H., \& Mudrack, P. (2008). The influence of ethics instruction, religiosity, and intelligence on cheating behavior. Journal of Business Ethics, 82(3), 557-571.

Bodkin, C. \& Stevenson, T. (2007). University students perceptions regarding ethical marketing practices: Affecting change through instructional techniques. Journal of Business Ethics, 72, 207-228.

Bratton, V. \& Strittmatter, C. (2013). To cheat of not to cheat?: The role of personality in academic and business ethics. Ethics \& Behavior, 23(6), 427-444

Brown, B. S., \& Choong, P. (2005). An investigation of academic dishonesty among business students at public and private United States universities. International Journal of Management, 22(2), 201.

Burks, B. D., \& Sellani, R. J. (2008). Ethics, religiosity, and moral development of business students. Journal of Leadership, Accountability and Ethics, 49.

Burton, J. H., Talpade, S., \& Haynes, J. (2011). Religiosity and test-taking ethics among Business School students. Journal of Academic and Business Ethics, 4, 1.

Cole, B. C., \& Smith, D. L. (1995). Effects of ethics instruction on the ethical perceptions of college business students. Journal of Education for Business, 70(6), 351-356.

Comegys, C. (2010). The impact of religiously affiliated universities and courses in ethics and religious studies on students' attitude toward business ethics. Contemporary Issues in Education Research, 3(6), 35-44. 
Conroy, S. J., \& Emerson, T. L. (2004). Business ethics and religion: Religiosity as a predictor of ethical awareness among students. Journal of Business Ethics, 50(4), 383-396.

Cotter, J. W., De Berry, T. W., Haen, J. J., Molnar, K. K., \& Vandenberg, A. (2016). Proceedings of International Business \& Education Conferences, 2016: Students' ethical perceptions: Analysis of religiously-affiliated institutions of similar size. Orlando, FL.

Cotter, J. W., De Berry, T. W., Haen, J. J., Molnar, K. K., \& Vandenberg, A. (2017). Proceedings of Business \& Education Conferences 2017: Students' Ethical Perceptions: Analysis of Religiously-Affiliated Institutions of Similar Size Longitudinal Results - Year 2, International. San Diego, CA.

Davis, S. F. (1993). Cheating in college is for a career: Academic dishonesty in the 1990s. Paper presented at the Annual Meeting of the Southeastern Psychological Association, Atlanta, GA.

Greening, T., J. Kay, \& Kummerfeld, B. (2004). Proceedings of Sixth Australasian Computing Education Conference 2014: Integrating ethical content into computing curricula, conferences in research and practice in information technology 30. Dunedin, NZ.

Guo, X. (2011). Understanding student plagiarism: An empirical study in accounting education. Accounting Education, 20(1), 17-37.

Hair, J., Anderson, R., Tatham, R. \& Black, W. (1995). Multivariate data analysis, $4^{\text {th }}$ Ed., Englewood Cliffs, NJ: Prentice-Hall.

Kisamore, J., Stone, T., \& Jawahar, I. I. (2007). Academic integrity: The relationship between individual and situational factors on misconduct contemplations. Journal of Business Ethics, 75(4), 381-394.

Knotts, T. L., Lopez, T. B., \& Mesak, H. I. (2000). Ethical judgments of college students: An empirical analysis. Journal of education for business, 75(3), 158-163.

Kuntz, J. R. C. \& Butler, C. (2014). Exploring individual and contextual antecedents of attitudes toward the acceptability of cheating and plagiarism. Ethics \& Behavior, 24(6), 478-494.

Kurpis, L. V., Beqiri, M. S., \& Helgeson, J. G. (2008). The effects of commitment to moral self-improvement and religiosity on ethics of business students. Journal of Business Ethics, 80(3), 447-463.

Lawson, R. A. (2004). Is classroom cheating related to business students' propensity to cheat in the "real world"? Journal of Business Ethics, 49(2), 189-199.

McCabe, D. L. \& Trevino, L. K. (1997). Individual and contextual influences on academic dishonesty: A multicampus investigation. Research in Higher Education, 38, 379-396.

Molnar, K., Kletke, M. \& Chongwatpol, J. (2008). Ethics vs. IT ethics: Do undergraduate students perceive a difference? Journal of Business Ethics, 83(4), 657-671.

Molnar, K., Kletke, M. \& Rampal, R. (2008). Proceedings of Decision Sciences Institutes 2008: A pilot study of factors that influence undergraduate students' opinions of IT. Boston, MA.

Molnar, K., Kletke, M., \& Jenkel, I. (2009). Proceedings of Decision Sciences Institutes 2009: Does the type of institution influence undergraduate students' ethical opinions. New Orleans, LA.

Niiya, Y., Ballantyne, R., North, M. S. \& Crocker, J. (2008). Gender, contingencies of self-worth, and achievement goals as predictors of academic cheating in a controlled laboratory setting. Basic and Applied Social Psychology, 30, 76-83.

Nonis, S., \& Swift, C. O. (2001). An examination of the relationship between academic dishonesty and workplace dishonesty: A multicampus investigation. Journal of Education for Business, 77(2), 69-77.

Rakovski, C. C. \& Levy, E. S. (2007). Academic dishonesty: Perceptions of business students. College Student Journal, 41, 466-481.

Ruegger, D., \& King, E. W. (1992). A study of the effect of age and gender upon student business ethics. Journal of Business Ethics, 11(3), 179-186.

Simon, C. A., Carr, J. R., McCullough, S. M., Morgan, S. J., Oleson, T., \& Ressel, M. (2004). Gender, student perceptions, institutional commitments and academic dishonesty: Who reports in academic dishonesty cases? Assessment and Evaluation in Higher Education, 29, 75-90.

Sims, R. L. (1993). The relationship between academic dishonesty and unethical business practices. Journal of Education for Business, 68(4), 207-211.

Smyth, M. L., \& Davis, J. R. (2004). Perceptions of dishonesty among two-year college students: Academic versus business situations. Journal of Business Ethics, 51(1), 63-73.

Smyth, L. S., Davis, J. R., \& Kroncke, C. O. (2009). Students' perceptions of business ethics: Using cheating as a surrogate for business situations. Journal of Education for Business, 84(4), 229-239.

Vitell, S. (2009). The role of religiosity in business and consumer ethics: A review of the literature. Journal of Business Ethics, 90, 155-167.

Wilhelm, W. J. (2004). Determinants of moral reasoning: Academic factors, gender, richness-of-life experiences, and religious preferences. Delta Pi Epsilon Journal, 46(2), 105-123.

Willson, L. R. (2016). Religiosity and honesty: Still searching for the elusive relationship. Journal of Psychology \& Christianity, 35(3), 195-203.

Yang, S. C., \& Huang, C-L. (2013). An investigation of college students' perceptions of academic dishonesty, reasons for dishonesty, achievement goals, and willingness to report dishonest behavior. Ethics \& Behavior, 23(6), 501-522. 